\title{
Korelasi Power Otot Tungkai, Kekuatan Otot Lengan, dan Koordinasi Mata-Tangan terhadap Ketepatan Smash Bulutangkis
}

\author{
Tegar Digantara, Ngadiman, Rifqi Festiawan, Indra Jati Kusuma, Bayu Suko Wahono
}

Universitas Jenderal Soedirman, Indonesia

Diterima: 25 Agustus 2020. Direvisi: 31 September 2020. Disetujui: 6 Oktober 2020

\begin{abstract}
ABSTRAK Olahraga bulutangkis memiliki beberapa teknik pukulan, salah satunya smash yang membutuhkan beberapa komponen fisik sebagai penunjang keberhasilan melakukan pukulan smash. Penelitian ini bertujuan untuk mengetahui hubungan antara power otot tungkai, kekuatan otot lengan, dan koordinasi mata tangan terhadap ketepatan smash bulutangkis. Penelitian ini merupakan penelitian korelasional, bertujuan untuk mencari hubungan antara variabel bebas power otot tungkai, kekuatan otot lengan, dan koordinasi mata tangan terhadap variabel terikat ketepatan smash. Sampel pada penelitian ini berjumlah 20 atlet anggota PB Delta Purwokerto. Teknik analisis data menggunakan uji korelasi sederhana dan regresi berganda. Berdasarkan hasil analisis data, diperoleh nilai koefisien korelasi hubungan power otot tungkai dengan ketepatan smash sebesar 0,571. Koefisien korelasi kekuatan otot lengan dengan ketepatan smash sebesar 0,735. Koefisien korelasi koordinasi mata tangan dengan ketepatan smash sebesar 0,520. Sedangkan hasil dari $\mathrm{f}$ hitung $>\mathrm{f}$ tabel $(17,364>3,49)$ dengan nilai probabilitas sebesar 0,000. Dari hasil analisis data menunjukkan bahwa terdapat hubungan yang signifikan antara power otot tungkai, kekuatan otot lengan, dan koordinasi mata tangan dengan ketepatan smash bulutangkis.
\end{abstract}

Kata Kunci: Bulutangkis, Komponen Fisik, Smash

ABSTRACT Badminton has several hit techniques; one of them is smash which requires several physical components as a support for the success of making a smash. This study was to determine the correlation between leg muscle power, arm muscle strength and hand eye coordination on badminton smashes. This study was a correlational study and the purpose was to find out the correlation between the independent variable of leg muscle power, arm muscle strength and hand eye coordination to the dependent variable smash accuracy. This study had 20 of PB Delta Purwokerto athletes as the subjects. The researcher used product moment correlation test to analyze the data. Based on the data analysis, the correlation coefficient value between the leg muscle power and the accuracy of the smash was 0.571, the correlation coefficient between arm muscle strength and smash accuracy was 0.735 , meanwhile between the hand eye coordination and smash accuracy was 0.520 . The result of $f>$ table $f(17,364>3,49)$ with a probability value of 0,000 . The result of the data analysis indicated that there was a significant correlation among leg muscle power, arm muscle strength, and hand eye coordination with the accuracy of badminton smashes.

Keywords: Badminton, Physical Component, Smashes

\section{PENDAHULUAN}

Olahraga mempunyai tujuan untuk menciptakan manusia yang memiliki kesehatan jasmani, kepribadian yang baik dan berbudi pekerti luhur, memiliki kemauan yang kuat untuk meraih prestasi yang maksimal, serta merupakan salah satu dari bagian sektor pembangunan manusia seutuhnya di Indonesia, salah satu olahraga yang dimaksud adalah bulutangkis (Festiawan et al., 2020; Widanita et al., 2020) .

Bulutangkis merupakan olahraga yang berkembang, baik tingkat nasional maupun internasional dari sekian banyak cabang olahraga. Menurut Arduta et al (2020) menjelaskan bahwa olahraga permainan bulutangkis adalah salah satu dari banyak olahraga yang terkenal pada benua asia khususnya di negara Indonesia sajak dahulu hingga saat ini. Maka dari itu bulutangkis adalah cabang olahraga yang sangat digemari oleh semua kalangan. Sama halnya dengan olahraga lain, pada umumnya bulutangkis memiliki berbagai macam teknik dasar yang harus/ wajib dikuasai.

Menurut Hermansyah, Imanudin and Badruzaman (2017) olahraga bulutangkis memiliki beberapa teknik dasar yang harus dikuasai yaitu cara memegang raket, sikap siap gerakan kaki, dan gerak memukul. Nofrizal (2019) mengatakan bahwa permainan bulutangkis terdiri dari 6 macam teknik yaitu "Servis, lob, drop shoot, smash, drive dan net shoot" yang merupakan garis besar dalam teknik pukulan.

Menurut Surahman, Yeni and Sanusi, (2019) mengatakan bahwa teknik yang paling dominan untuk melakukan serangan guna memperoleh poin pada permainan bulutangkis adalah smash. Nofrizal (2019) mengatakan bahwa pukulan bola (shutlecock) tajam me- 
nuju area lawan mengarah ke bawah dengan kecepatan maksimal dan tepat sasaran dalam permainan bulutangkis disebut smash. Maka dari itu pukulan smash merupakan pukulan yang harus dikuasai dengan baik pada permainan bulutangkis. Putra (2019) mengatakan bahwa aspek kekuatan, daya ledak otot, fleksibilitas dan koordinasi yang baik dibutuhkan saat melakukan pukulan smash.

Power merupakan kemampuan suatu otot yang digunakan dapat bekerja secara maksimal dengan waktu sesingkat mungkin yang menunjuk kepada kekuatan dan kecepatan waktu (Saputra et al., 2020). Maka dari itu power otot tungkai adalah kekuatan kontraksi otot secara eksplosif pada otot bagian tungkai. Sesuai dengan prinsip smash pada bulutangkis yaitu semakin tinggi loncatan maka pukulan smash semakin tajam dan tepat.

Selain aspek diatas, agar dapat memiliki kemampuan smash yang baik, harus didukung dengan unsur-unsur penunjang lain yang saling berkaitan. Unsur-unsur itu diantaranya kekuatan otot lengan dan koordinasi mata-tangan. Kekuatan merupakan kemampuan suatu otot dalam melakukan kontraksi yang diperoleh dalam sekali usaha secara maksimal (Ismaryanti, 2008). Dalam hal ini kekuatan diperlukan untuk mendapatkan pukulan yang keras sehingga shuttlecock melaju dengan cepat dan sulit dikembalikan. Lebih lanjut, koordinasi adalah sebagai komponen yang memilki pengaruh diantara beberapa kelompok otot dalam melakukan aktivitas kerja (Handayani, 2018). Maka dari itu koordinasi mata tangan merupakan kemampuan seseorang dalam melakukan penglihatan untuk mengkoordinasikan/ mengelola informasi yang diperoleh melalui salah satu bagian panca indra yaitu mata untuk dapat mengarahkan dan memprediksikan gerakan tangan sesuai dengan tugas yang akan diberikan. Kemampuan fisik menjadi salah satu unsur dominan penunjang kualitas smash.

Dari hasil studi awal, diperoleh hasil bahwa kemampuan smash atlet PB Delta berjumlah 30 anak, ternyata 21 anak atau sebanyak $70 \%$ belum menguasai teknik pukulan tersebut. Masalah yang ditemui bervariatif yaitu berupa masih banyaknya atlet yang pukulan smashnya tidak tepat sasaran/ tidak mengarah ke dalam lapangan, kekuatan ayunan lengan yang masih lemah sehingga mengakibatkan pukulan sering tersangkut di net, kurangnya pengamatan saat bola datang serta respons tubuh saat memukul bola tersebut (koordinasi mata tangan), yang tentunya menguntungkan bagi pihak lawan. Apabila hal ini dibiarkan secara berkelanjutan, maka akan mempengaruhi penampilan siswa pada kemampuan smash bulutangkis sehingga dapat menimbulkan permasalahan baru yang menghambat prestasi siswa, khususnya pada kemampuan smash bulutangkis.

Sementara itu dari kajian literatur terdahulu diketahui bahwa penelitian dari (Ridlo, 2015) mengatakan bahwa koordinasi mata tangan, power lengan, dan percaya diri berhubungan dengan keterampilan smash bulutangkis, sedangkan (Zaenal Abidin \& Wiriawan, 2018) menyebutkan bahwa terdapat kontribusi yang signifikan pada tinggi loncatan dan kekuatan otot lengan terhadap ketepatan pukulan jump smash.

Permasalahan beserta hasil penelitian tersebut menjadi dasar dari penelitian yang dilakukan untuk mengetahui korelasi antara power otot tungkai, kekuatan otot lengan, dan koordinasi mata-tangan dengan ketepatan smash ini.

\section{METODE}

Desain penelitian yang digunakan adalah korelasional dengan pendekatan cross sectional yang memiliki tujuan untuk mengetahui hubungan antara power otot tungkai, kekuatan otot lengan dan koordinasi matatangan dengan ketepatan smash (Sugiyono, 2012). Pelaksanaan penelitian ini berada di PB Delta Purwokerto pada bulan Juli 2020. Populasi pada penelitian ini merupakan seluruh anggota klub Persatuan Bulutangkis Delta usia 10-12 tahun dengan jumlah 20 anak. Teknik sampling menggunakan total sampling. Instrumen yang digunakan diantaranya: 1) Vertical Jump Test untuk mengukur power otot tungkai. 2) Push up selama 1 menit untuk mengukur kekuatan otot lengan. 3) Tes lempar tangkap bola untuk mengukur koordinasi mata-tangan. 4) Tes ketepatan smash dari (Nasution, 1993).

Analisis data yang digunakan antara lain: Uji prasyarat yang terdiri dari, 1) Uji Normalitas data menggunakan uji Shapiro Wilk. 2) Uji Linearitas Data, dengan metode Test for linearity. Analisis selanjutnya yaitu Uji Hipotesis, yang terdiri dari: 1) Uji Korelasi Sederhana dan 2) Uji Korelasi Ganda.

\section{HASIL DAN PEMBAHASAN}

\section{Hasil Data Power Otot Tungkai $\left(X_{1}\right)$}

Data hasil kemampuan powerotot tung- 
kai anggota PB Delta Purwokerto usia 10-12 Hasil Koordinasi Mata-Tangan ( $\left.\mathbf{X}_{3}\right)$. tahun dapat dilihat pada tabel 1 dibawah ini.

Data hasil kemampuan koordinasi

Tabel 1. Hasil analisis deskriptif variabel power otot tungkai

\begin{tabular}{lccc}
\hline Klasifikasi & Kelas Interval & Frek & $\%$ \\
\hline Sangat Baik & $>39$ & 1 & $5 \%$ \\
Baik & $33-38$ & 8 & $40 \%$ \\
Cukup & $27-32$ & 7 & $35 \%$ \\
Kurang Baik & $20-26$ & 3 & $15 \%$ \\
Sangat Kurang & $<18$ & 2 & $10 \%$ \\
\hline
\end{tabular}

Dari Tabel 1. Diatas, dapat diketahui bahwa tingkat power otot tungkai anggota $\mathrm{PB}$ Delta Purwokerto usia 10-12 tahun ada 1 anak yang memiliki power otot tungkai sangat baik dengan presentase $5 \%$, ada 8 anak yang masuk kategori baik dengan presentase $40 \%$, ada 7 anak masuk kategori cukup dengan presentase $25 \%$, ada 3 anak yang masuk kategori kurang baik dengan presentase 15\% dan ada 2 anak masuk kategori sangat kurang dengan presentase $10 \%$. Dari hasil itu diketahui bahwa presentase tertinggi tingkat keseimbangan siswa berada pada kategori baik.

\section{Hasil Data Kekuatan Otot Lengan $\left(X_{2}\right)$}

Data hasil kemampuan kekuatan otot lengan anggota PB Delta Purwokerto usia 1012 tahun dapat dilihat pada tabel 1 dibawah ini.

Tabel 2. Data Hasil Kekuatan Otot Lengan

\begin{tabular}{lccc}
\hline Klasifikasi & Kelas Interval & Frek & $\%$ \\
\hline Sangat Baik & $>33$ & 2 & $10 \%$ \\
Baik & $31-32$ & 5 & $25 \%$ \\
Cukup & $29-30$ & 5 & $25 \%$ \\
Kurang Baik & $27-28$ & 5 & $25 \%$ \\
Sangat Kurang & $<25$ & 3 & $15 \%$ \\
\hline
\end{tabular}

Dari Tabel 2. Diatas, dapat diketahui bahwa tingkat kekuatan otot lengan anggota PB Delta Purwokerto usia 10-12 tahun ada 2 anak yang memiliki kekuatan otot lengan sangat baik dengan presentase $10 \%$, ada 5 anak yang masuk kategori baik dengan presentase $25 \%$, ada 5 anak masuk kategori cukup dengan presentase $25 \%$, ada 5 anak yang masuk kategori kurang baik dengan presentase 25\% dan ada 3 anak masuk kategori sangat kurang dengan presentase $15 \%$. -tangan anggota PB Delta Purwokerto usia 10-12 tahun dapat dilihat pada tabel 3 dibawah ini.

Tabel 3. Hasil analisis deskriptif variabel koordinasi mata-tangan

\begin{tabular}{lccc}
\hline Klasifikasi & Kelas Interval & Frek & $\%$ \\
\hline Sangat Baik & $>17$ & 2 & $10 \%$ \\
Baik & $15-16$ & 7 & $35 \%$ \\
Cukup & 14 & 7 & $35 \%$ \\
Kurang Baik & 13 & 3 & $15 \%$ \\
Sangat Kurang & $<12$ & 1 & $5 \%$ \\
\hline
\end{tabular}

Dari Tabel 3. Diatas, dapat diketahui bahwa tingkat koordinasi mata-tangan anggota PB Delta Purwokerto usia 10-12 tahun ada 2 anak yang memiliki koordinasi mata-tangan sangat baik dengan presentase $10 \%$, ada 7 anak yang masuk kategori baik dengan presentase $35 \%$, ada 7 anak masuk kategori cukup dengan presentase $35 \%$, ada 3 anak yang masuk kategori kurang baik dengan presentase $15 \%$ dan ada 1 anak masuk kategori sangat kurang dengan presentase $5 \%$.

Tabel 4. Hasil analisis deskriptif variabel ketepatan smash

\begin{tabular}{lccc}
\hline Klasifikasi & Kelas Interval & Frek & $\%$ \\
\hline Sangat Baik & $69-70$ & 2 & $10 \%$ \\
Baik & $61-68$ & 3 & $15 \%$ \\
Cukup & $52-60$ & 9 & $45 \%$ \\
Kurang Baik & $44-51$ & 5 & $25 \%$ \\
Sangat Kurang & $40-43$ & 1 & $5 \%$ \\
\hline
\end{tabular}

Dari Tabel 4. Diatas, dapat diketahui bahwa tingkat ketepatan smash anggota PB Delta Purwokerto usia 10-12 tahun ada 2 anak yang memiliki ketepatan smash sangat baik dengan presentase $10 \%$, ada 3 anak yang masuk kategori baik dengan presentase $15 \%$, ada 9 anak masuk kategori cukup dengan presentase $45 \%$, ada 5 anak yang masuk kategori kurang baik dengan presentase $25 \%$ dan ada 1 anak masuk kategori sangat kurang dengan presentase 5\%. Dari hasil itu diketahui bahwa presentase tertinggi tingkat ketepatan smash anggota PB Delta Purwokerto berada pada kategori cukup. 
Hasil Uji Prasyarat

Uji prasyarat yang dilakukan terdiri dari uji normalitas data, dan uji linearitas data. Hasil dari masing-masing uji dapat dilihat pada deskripsi dibawah ini.

\section{Uji Normalitas}

Uji Kolmogorov Smirnov digunakan untuk menguji normalitas data, karena jumlah sampel yang lebih dari 50. Data dikatakan normal jika nilai Signifikansi lebih besar dari 0,05 (Sig> 0,05). Hasil uji normalitas data dapat dilihat pada tabel dibawah ini:

Tabel 5. Uji Normalitas Data

\begin{tabular}{lccc}
\hline \multirow{2}{*}{ Data } & \multicolumn{3}{c}{ Shapiro-Wilk } \\
\cline { 2 - 4 } & Statistic & $\mathrm{N}$ & Sig. \\
\hline Power Otot Tungkai & .928 & 20 & .144 \\
Kekuatan Otot Lengan & .967 & 20 & .690 \\
Koordinasi Mata Tangan & .936 & 20 & .197 \\
Ketepatan Smash & .954 & 20 & .432 \\
\hline
\end{tabular}

Dari tabel di atas, diketahui bahwa nilai signifikansi power otot tungkai adalah 0,144, nilai signifikansi kekuatan otot lengan adalah 0,690 nilai signifikansi koordinasi matatangan adalah 0,197, dan nilai signifikansi ketepatan smash sebesar 0,432 yang artinya nilai tersebut lebih besar dari 0,05, sehingga dapat dikatakan bahwa data yang telah diteliti terdistribusi normal.

\section{Uji Linearitas}

Uji linieritas menggunakan test for linearity. Kriteria linearitas yang digunakan adalah sig. > 0,05. Hasil uji linearitas dapat dilihat pada tabel dibawah ini:

Tabel 6. Uji Linearitas Data

\begin{tabular}{lcl}
\hline Data & Sig. & Keterangan \\
\hline $\begin{array}{l}\text { Power Otot Tungkai * } \\
\text { Ketepatan Smash }\end{array}$ & .957 & Linear \\
$\begin{array}{l}\text { Kekuatan Otot Lengan } \\
\text { * Ketepatan Smash }\end{array}$ & .804 & Linear \\
$\begin{array}{l}\text { Koordinasi Mata Tan- } \\
\text { gan Ketepatan Smash }\end{array}$ & .941 & Linear \\
\hline
\end{tabular}

Dari tabel diatas, dapat diketahui bahwa ketiga variabel pada tabel tersebut memiliki nilai signifikansi yang lebih besar 0,05 yaitu; power otot tungkai sebesar 0,957, kekuatan otot lengan sebesar 0,804 , koordinasi mata tangan sebesar 0,941, sehingga dapat disimpulkan jika ketiga variabel bebas tersebut dengan data ketepatan smash pada penelitian ini linear.

\section{Hasil Uji Hipotesis}

Uji hipotesis yang dilakukan terdiri dari Uji Korelasi Sederhana dan 2) Uji Korelasi Ganda.

\section{Hubungan antara Power Otot Tungkai den- gan Ketepatan Smash}

Uji hipotesis pertama menggunakan uji korelasi product moment dengan membandingkan antara hasil power otot tungkai dengan hasil ketepatan smash, hasil analisis dapat dilihat pada tabel dibawah ini.

Tabel 7. Uji Hipotesis Power Otot Tungkai

\begin{tabular}{llll}
\hline Korelasi & $\mathrm{R}_{\text {hitung }}$ & $\mathrm{R}_{\text {tabel }}$ & Keterangan \\
\hline $\begin{array}{l}\text { Power otot } \\
\text { tungkai den- }\end{array}$ & 0,571 & 0,444 & \\
gan Ketepa- & & & Berhubungan \\
tan smash & & & \\
\hline
\end{tabular}

Dari tabel diatas, diketahui bahwa nilai $R_{\text {hitung }}$ sebesar 0,571 sedangkan nilai $R_{\text {tabel }}$ dengan jumlah $\mathrm{n}=20$ adalah 0,444. Maka nilai $R_{\text {hitung }}>R_{\text {tabel(20) }}$ yang artinya ada korelasi antara keseimbangan dengan ketepatan smash.

Hubungan antara Kekuatan Otot Lengan
dengan ketepatan Smash.
Uji hipotesis pertama menggunakan uji korelasi product moment dengan membandingkan antara hasil kekuatan otot lengan dengan hasil ketepatan smash, hasil analisis dapat dilihat pada tabel 8 dibawah ini.

Tabel 8. Uji Hipotesis Kekuatan Otot Lengan

\begin{tabular}{llll}
\hline Korelasi & $R_{\text {hitung }}$ & $R_{\text {tabel }}$ & Keterangan \\
\hline $\begin{array}{l}\text { Kekuatan otot } \\
\text { lengan dengan }\end{array}$ & 0,735 & 0,444 & Berhubungan \\
$\begin{array}{l}\text { Ketepatan } \\
\text { smash }\end{array}$ & & & \\
\hline
\end{tabular}

Dari tabel diatas, diketahui bahwa nilai $R_{\text {hitung }}$ sebesar 0,735 sedangkan nilai $R_{\text {tabel }}$ dengan jumlah $n=20$ adalah 0,444 . Maka nilai $R_{\text {hi- }}$ tung $>R_{\text {tabel(60) }}$ yang artinya ada korelasi antara kekuatan otot lengan dengan ketepatan smash.

\section{Hubungan antara Koordinasi Mata-Tangan dengan Ketepatan Smash.}

Uji hipotesis pertama menggunakan 
uji korelasi product moment dengan membandingkan antara hasil koordinasi matatangan dengan hasil ketepatan smash, hasil analisis dapat dilihat pada tabel 9 dibawah ini.

Tabel 9. Uji Hipotesis Koordinasi Mata-Tangan

\begin{tabular}{lccl}
\hline Korelasi & $\mathrm{R}_{\text {hitung }}$ & $\mathrm{R}_{\text {tabel }}$ & Keterangan \\
\hline $\begin{array}{l}\text { Koordinasi } \\
\text { mata-tangan }\end{array}$ & 0,520 & 0,444 & Berhubungan \\
$\begin{array}{l}\text { dengan Kete- } \\
\text { patan smash }\end{array}$ & & & \\
\hline
\end{tabular}

Dari tabel diatas, diketahui bahwa nilai $R_{\text {hitung }}$ sebesar 0,520 sedangkan nilai $R_{\text {tabel }}$ dengan jumlah $n=20$ adalah 0,444 . Maka nilai $R_{h i-}$ tung $>R_{\text {tabel(60) }}$ yang artinya ada korelasi antara koordinasi mata-tangan dengan ketepatan smash.

Hubungan antara Power Otot Tungkai, Kekuatan Otot Lengan, dan Koordinasi MataTangan dengan Ketepatan Smash.

Uji hipotesis ketiga menggunakan uji korelasi berganda dengan membandingkan antara hasil power otot tungkai, kekuatan otot lengan, dan koordinasi mata-tangan dengan ketepatan smash, hasil analisis dapat dilihat pada tabel 10 dibawah ini.

Tabel 10. Uji hipotesis Power Otot Tungkai, Kekuatan Otot Lengan, dan Koordinasi MataTangan dengan Ketepatan Smash

\begin{tabular}{lccl}
\hline Korelasi & $F_{\text {hitung }}$ & $F_{\text {tabel }}$ & Keterangan \\
\hline $\begin{array}{l}\mathrm{X}_{1^{\prime}} \mathrm{X}_{2^{\prime}} \text { dan } \mathrm{X}_{3} \\
\text { dengan } \mathrm{Y}\end{array}$ & 17,364 & 3,49 & Berhubungan \\
\hline
\end{tabular}

Dari tabel diatas, diketahui bahwa nilai $\mathrm{F}_{\text {hitung }}$ sebesar 17,364 sedangkan nilai $\mathrm{R}_{\text {tabel }}$ dengan jumlah $n=20$ adalah 3,49. Maka nilai $F_{\text {hitung }}$ $>\mathrm{F}_{\text {tabel(20) }}$. Dapat disimpulkan bahwa ada korelasi antara power otot tungkai, kekuatan otot lengan, dan koordinasi mata-tangan dengan ketepatan smash.

Pada olahraga bulutangkis tentu terdapat beberapa teknik yang harus dikuasai, salah satunya smash. Untuk menguasai teknik ketepatan smash, diperlukan suatu bentuk latihan yang terprogram dan terdiri dari berbagai macam aspek serta penerapan metode latihan didasarkan pada kemampuan awal atlet. Pemberian latihan drill merupakan salah satu contoh yang dapat digunakan untuk meningkatkan ketepatan smash. Hal ini sejalan den- gan penelitian dari (Prayadi \& Rachman, 2013) yang menyatakan bahwa ada pengaruh interaksi yang signifikan antara metode latihan dan power otot lengan terhadap peningkatan smash bulutangkis.

Penelitian ini memiliki tujuan untuk mengetahui korelasi antara power otot tungkai, kekuatan otot lengan, dan koordinasi mata-tangan dengan ketepatan smash anggota PB Delta Purwokerto usia 10-12 tahun. Hasil-hasil penelitian diantaranya:

\section{Hubungan antara Power Otot Tungkai den- gan Ketepatan Smash}

Dari hasil uji korelasi power otot tungkai dengan ketepatan smash diperoleh nilai $r_{x 1 . y}$ $=0,571<\mathrm{r}_{(0,05)(20)=} 0,444$ nilai ini menunjukan bahwa terdapat hubungan yang signifikan diantara keduanya. Hasil ini tentu menunjukkan bahwa seorang pemain bulutangkis perlu memiliki power otot tungkai yang baik karena memiliki hubungan yang positif dengan ketepatan smash yang artinya jika seseorang memiliki power otot tungkai yang baik maka ketepatan smash pun akan baik.

Penelitian lain menyebutkan jika power otot tungkai pemain yang baik merupakan salah satu faktor yang dapat menunjang ketepatan smash dalam olahraga bulutangkis dengan faktor pendukung yaitu power otot tungkai, karena power otot tungkai berfungsi dalam kontribusi hasil loncatan, karena ketika semakin tinggi loncatan yang dihasilkan maka pukulan smash akan semakin tajam (Setyawan, 2016).

Power otot tungkai yang baik sangat berperan dalam melakukan smash, karena semakin tinggi loncatan yang dihasilkan maka menuguntungkan bagi pemain untuk melakukan smash yang tajam ke area lawan. Hal ini membedakan dengan penelitian sebelumnya milik (Zaenal Abidin \& Wiriawan, 2018) menyatakan bahwa tidak ada hubungan antara tinggi loncatan dengan smash bulutangkis yang menunjukkan nilai sig. sebesar 0,332 >0,05. Sedangkan penelitian ini menunjukkan nilai sig. sebesar 0,009<0,05.

\section{Hubungan antara Kekuatan Otot Lengan dengan ketepatan Smash}

Dari hasil uji korelasi kekuatan otot lengan dengan ketepatan smash diperoleh nilai $r_{x 2 . y}=0,735<r_{(0,05)(20)}=0,444$ nilai ini menunjukan bahwa terdapat hubungan yang signifikan diantara keduanya. Hasil ini tentu menunjukkan bahwa seorang pemain bulu- 
tangkis perlu memiliki kekuatan otot lengan yang baik karena memiliki hubungan yang positif dengan ketepatan smash yang artinya jika seseorang memiliki kekuatan otot lengan yang baik maka ketepatan smash pun akan baik.

Penelitian lain menyebutkan jika kekuatan otot lengan pemain yang baik merupakan salah satu faktor yang dapat menunjang ketepatan smash dalam olahraga bulutangkis dengan faktor pendukung yaitu kekuatan otot lengan, karena kekuatan otot lengan berfungsi dalam kontribusi hasil pukulan smash, karena semakin baik kekuatan otot lengan yang dimiliki maka akan dengan mudah mengatur tingkat kecepatan dan kekerasan ketika melakukan smash (Hidayat, 2014).

Kekuatan otot lengan yang baik sangat berperan dalam melakukan smash, karena semakin keras dan cepat pukulan yang dihasilkan maka menuguntungkan bagi pemain untuk meraih poin. Hal ini sejalan dengan penelitian sbeleumnya milik (Ridlo, 2015) menyatakan bahwa ada hubungan antara power lengan dengan smash bulutangkis yang menunjukkan nilai sig. sebesar 0,003 < 0,05. Sedangkan penelitian ini menunjukkan nilai sig. sebesar $0,000<0,05$.

\section{Hubungan antara Koordinasi Mata-Tan- gan dengan Ketepatan Smash}

Dari hasil uji korelasi koordinasi matatangan dengan ketepatan smash diperoleh nilai $\mathrm{r}_{\mathrm{x} 3 \mathrm{y}}=0,520<\mathrm{r}_{(0,05)(20)=} 0,444$ nilai ini menunjukan bahwaterdapat hubungan yang signifikan diantara keduanya. Hasil ini tentu menunjukkan bahwa seorang pemain bulutangkis perlu memiliki koordinasi mata-tangan yang baik karena memiliki hubungan yang positif dengan ketepatan smash yang artinya jika seseorang memiliki koordinasi mata-tangan yang baik maka ketepatan smash pun akan baik.

Penelitian lain menyebutkan jika koordinasi mata-tangan pemain yang baik merupakan salah satu faktor yang dapat menunjang ketepatan smash dalam olahraga bulutangkis dengan faktor pendukung yaitu koordinasi mata-tangan, karena semakin baik koordinasi mata tangan yang dimiliki maka kemampuan dalam melihat situasi untuk menjatuhkan bola ke area pertahanan lawan akan semakin tepat (Ridlo, 2015).

Koordinasi mata-tangan yang baik sangat berperan dalam melakukan smash, karena semakin baik melihat situasi di lapangan maka akan lebih mudah mengarahkan shuttlecock ke area lawan. Hal ini sejalan dengan penelitian sebelumnya milik (Putra, 2019) menyatakan bahwa ada hubungan antara koordinasi matatangan dengan smash bulutangkis yang menunjukkan nilai Rhitung sebesar 0,496. Sedangkan penelitian ini menunjukkan nilai Rhitung sebesar 0,520 .

Hubungan antara Power Otot Tungkai, Kekuatan Otot Lengan, dan Koordinasi MataTangan dengan Ketepatan Smash.

Dari hasil uji korelasi antara power otot tungkai, kekuatan otot lengan dan koordinasi mata-tangan dengan ketepatan smash diperoleh nilai $F_{\text {hitung }}=17,364<$ Ftabel $_{=} 3,49$, nilai ini menunjukan bahwa terdapat hubungan yang signifikan diantara ketiga variabel $\mathrm{x}$ dengan variabel y.

Dengan hasil ini maka diketahui bahwa power otot tungkai, kekuatan otot lengan dan koordinasi mata-tangan jika disatukan memiliki hubungan yang signifikan secara bersama-sama dengan ketepatan smash, dengan kata lain jika kelentukan power otot tungkai, kekuatan otot lengan dan koordinasi matatangan pemain bagus maka tentu memiliki ketepatan smash yang bagus pula.

Hal ini sejalan dengan penelitian (Setyawan, 2016) yang menyebutkan ada hubungan yang signifikan antara kekuatan otot lengan dan power otot tungkai dengan ketepatan smash siswa sekolah bulutangkis di PB Mataram Raya Sleman. Dengan ini maka seorang pelatih perlu mempertimbangkan faktor-faktor penentu yang perlu ditingkatkan untuk menunjang keberhasilan melakukan smash yang baik, diantaranya power otot tungkai, kekuatan otot lengan dan koordinasi mata-tangan yang berpengaruh dengan hasil ketepatan smash.

\section{SIMPULAN}

Dari hasil dan pembahasan penelitian ini dapat ditarik kesimpulan bahwa 1) Power otot tungkai memiliki korelasi dengan ketepatan smash, 2) Kekuatan otot lengan memiliki korelasi dengan ketepatan smash 3) Koordinasi mata-tangan memiliki korelasi dengan ketepatan smash, dan 4) Power otot tungkai, kekuatan otot lengan dan koordinasi matatangan memiliki korelasi secara bersama-sama dengan ketepatan smash. 
DAFTAR PUSTAKA

Arduta, M. Z., Kusuma, I. J., \& Festiawan, R. (2020). Faktor Penentu Minat Siswa Smp Dalam Mengikuti Ekstrakurikuler Bulutangkis Di Purwokerto. Multilateral Jurnal Pendidikan Jasmani Dan Olahraga, 19(1), 41-51. https://doi.org/10.20527/multilateral.v19i1.8322

Festiawan, R., Raharja, A. T., Jusuf, J. B. K., \& Mahardika, N. A. (2020). The Effect of Oregon Circuit Training and Fartlek Training on the VO2Max Level of Soedirman Expedition VII Athletes. Jurnal Pendidikan Jasmani Dan Olahraga, 5(1), 62-69. https:/ / doi. org/10.17509/jpjo.v5i1.23183

Handayani, W. (2018). Hubungan Koordinasi Mata Tangan dan Kekuatan Otot Lengan dengan Ketepatan Hasil Servis Forehand. Wahana Didatik, 16(2), 256-266.

Hermansyah, R., Imanudin, I., \& Badruzaman, ,. (2017) Hubungan Power Otot Lengan Dan Koordinasi Dengan Kecepatan Dan Ketepatan Smash Dalam Cabang Olahraga Bulutangkis. Jurnal Terapan Ilmu Keolahragaan. https://doi.org/10.17509/jtikor. v2i1.5355

Hidayat, S. (2014). Pelatihan Olahraga (1st ed.). Yogyakarta: Graha Ilmu.

Ismaryanti. (2008). Tes $\mathcal{E}$ Pengukuran Olahraga. LPP UNS dan UNS Press.

Nasution, M. (1993). Validitas dan Realibilitas Instrumen Pukulan Smash dalam Permainan Bulutangkis bagi Pemain SeKotamadia Semarang. IKIP Semarang.

Nofrizal, D. (2019). Kontribusi Daya Ledak Otot Lengan Dan Kelentukan Terhadap Ketepatan Smash Dalam Cabang Olahraga Bulutangkis Anggota Klub Stkip Meranti Kabupaten Kepulauan Meranti. Curricula, 4(2), 69. https://doi.org/10.22216/ jcc.2019.v4i2.1124

Prayadi, H. Y., \& Rachman, H. A. (2013). Pengaruh Metode
Latihan dan Power Lengan Kemampuan Smash Bulutangkis. Jurnal Keolahragaan, 1(3), 63-71.

Putra, R. (2019). Kontribusi Daya Ledak Otot Lengan, Kelentukan Dan Koordinasi Mata-Tangan Terhadap Ketepatan Smash Atlet Bulutangkis Pb. Bintama Kerinci. Ensiklopedia of Journal, 1(3), 153-157.

Ridlo, A. F. (2015). Hubungan Antara Kordinasi Mata Tangan, Power Lengan Dan Percaya Diri Degan Keterampilan Smash Bulutangkis. Journal Research of Physical Education, 6(2), 223-232.

Saputra, S. H., Kusuma, I. J., \& Festiawan, R. (2020). Hubungan tinggi badan, panjang lengan dan daya tahan otot lengan dengan keterampilan bermain bulutangkis. Jurnal Pendidikan Olahraga, 9(1), 93108. https://doi.org/10.31571/jpo.v9i1.1744

Setyawan, I. (2016). Hubungan Antara Kekuatan Otot Lengan Dan Power Otot Tungkai Dengan Ketepatan Smash Dalam Permainan Bulutangkis Siswa Sekolah Bulutangkis Mataram Raya Sleman Tahun 2016. Jurnal Pendidikan Jasmani Kesehatan Dan Rekreasi, 5(8), 1-10.

Sugiyono. (2012). Metode Penelitian Kuantitatif, Kualitatif dan R \& D.Bandung:Alfabeta. Metode Penelitian Kuantitatif, Kualitatif Dan $R$ \& D.Bandung:Alfabeta. https:/ / doi.org/10.1017/CBO9781107415324.004

Surahman, F., Yeni, H. O., \& Sanusi, R. (2019). Pinggang Dengan Kemampuan Smash Bulutangkis Pada Ekstrakurikuler Siswa Sma N 2 Karimun. Jurnal Pendidikan MINDA, 1(1), 42-53.

Widanita, N., Sukamti, E. R., \& Festiawan, R. (2020). Hubungan Tingkat Intelligence Qoutient ( IQ ) dan Bakat dengan Hasil Kejuaraan Senam POPDA DIY. JTIKOR: Jurnal Terapan Ilmu Keolahragaan, 5(1), 41-50. https:/ / doi.org/10.17509/jtikor.v5i1.24463

Zaenal Abidin, M., \& Wiriawan, O. (2018). Kontribusi Tinggi Loncatan Dan Kekuatan Otot Lengan Terhadap Ketepatan Pukulan Jump Smash Cabang Oalhraga Bulutangkis. Jurnal Prestasi Olahraga, 1(2), 1-4. 